\title{
PHYSICAL PROPERTIES OF BEANS OF THE BRSMG MAJESTOSO CULTIVAR DURING DRYING
}

\author{
PROPRIEDADES FÍSICAS DE GRÃOS DE FEIJÃO CULTIVAR BRSMG \\ MAJESTOSO DURANTE A SECAGEM
}

\begin{abstract}
Aline Almeida da PAIXÃó ${ }^{1}$; Paulo Cesar CORRÊA ${ }^{1}$; Fernanda Machado BAPTESTINI² Juliana Soares ZEYMER ${ }^{1}$; Jaime Daniel BUSTOS-VANEGAS ${ }^{3}$

1. Universidade Federal de Viçosa, Departamento de Engenharia agrícola e Ambiental, Viçosa, MG, Brasil. aline@itagro.com.br; copace@ufv.br; juliana.zeymer@ufv.br; 2. Universidade Federal do Espírito Santo, Departamento de Engenharia Rural, Alegre, ES, Brasil. fernanda.baptestini@ufes.br; 3. Universidad del Cauca, Departamento de Agroindustria, Popayán, Colombia. jdbustosv@ut.edu.co
\end{abstract}

\begin{abstract}
Beans are the main source of protein of plant origin in the Brazilian diet, they also contain phenolic compounds, antioxidants, iron, fibers and vitamins. The BRSMG Majestoso cultivar belongs to the commercial group of carioca beans, displays high productivity, excellent health and a 90-day cycle, has high yield and is resistant to disease. The study of physical properties enables the prediction of agricultural products behavior relative to responses of physical and chemical treatments, in order to allow the maintenance of quality and safety of processed foods. The aim of the present study was to evaluate the effect of drying on the physical characteristics of beans of the BRSMG Majestoso cultivar. Beans with an initial moisture content of approximately 0.2660 d.b. (dry basis) were used, and dried at $40^{\circ} \mathrm{C}$. The following physical characteristics were determined: bulk density, unit density, intergranular porosity, 1000-grain weight, sphericity, circularity, geometric diameter, unit volume, projected area, surface area and the surface to volume ratio. Based on the results, a reduction in the moisture content of the beans promotes an increase in bulk density, unit density, porosity, sphericity, circularity and the surface to volume ratio. Conversely, the 1000-grain weight, geometric diameter, unit volume, projected area and surface area decreased as the moisture content of the beans was reduced.
\end{abstract}

KEYWORDS: Bulk density. Circularity. Phaseolus vulgaris. Porosity. Projected area. Sphericity.

\section{INTRODUCTION}

The BRSMG Majestoso cultivar together with other cultivars were developed through the Program for the Genetic Improvement of Beans for the State of Minas Gerais, and involved the Brazilian Agricultural Research Corporation (EMBRAPA), the Federal University of Viçosa (UFV), the Federal University of Lavras (UFLA), and the Minas Gerais Agricultural Research Corporation (EPAMIG).

According to researchers, this cultivar belongs to the commercial group of pinto beans, displays high productivity, excellent health and a 90-day cycle, has high yield and is resistant to disease. As for the technological and industrial quality of the beans, it was found that the cultivar, in addition to having beans that meet market requirements, has excellent culinary qualities, with a cooking time of around 28 to 29 minutes and a protein content of 23.9 to $23.7 \%$ (EPAMIG, 2016).

There is still no information on the physical properties of this bean cultivar during drying. Such information is important, as it assists in post-harvest processing and provides a set of data for engineers and designers of machines, structures and control processes, and affords greater efficiency in a given piece of equipment or operation (ARAUJO et al., 2014).

According to Resende et al. (2005), in addition to causing shrinkage, a reduction in the moisture content of the beans directly influences their physical properties during the drying process; as this is one of the most important steps during the post-harvest phase, understanding this behaviour is essential.

Data of bulk density and unit density in agricultural products are important in designing silos, conveyors, separators, and grain and seed classifiers. There are several factors that affect the density of plant material, the most important of which are the moisture content, the shape, and the surface of the product.

Knowledge of the intergranular porosity of a product, understood as one of its physical characteristics, is of paramount importance, as it is an integral part of the design of various structures such as silos, containers, boxes, packaging and transport units, in addition to being required for the study of heat and mass transfer in hydrodynamic, 
aerodynamic and thermoelectric processes (MATA; DUARTE, 2002).

Generally, volume is the physical characteristic of a product that suffers the most variation during drying, often resulting in a reduction in size or even geometric shape; indeed, it is these characteristics that determine the size and shape of the holes in the sieves used in processing agricultural products after harvest (ARAUJO et al., 2014). According to Mayor and Sereno (2004), a reduction in the moisture content of a product can cause damage to its cellular structure, as well as variations in its shape and a reduction in its size.

Considering the importance of developing a new bean cultivar, the aim of this study was to determine the effect of moisture content on its principal physical properties: bulk density, unit density, porosity, 1000-grain weight, shape, projected area, surface area and surface to volume ratio.

\section{CONTENTS}

Beans from the BRSMG Majestoso cultivar of the pinto group were harvested by hand in the experimental area of the Agricultural Research Corporation of Minas Gerais (EPAMIG), in the city of Oratórios. They were then purged with fumigants to avoid possible interference from infestations that had occurred in the field.

Beans with a moisture content of approximately 0.2660 d.b. (dry basis) were homogenised and dried in a forced air circulation oven at $40^{\circ} \mathrm{C}$. Changes in the moisture content were monitored throughout the drying process using the gravimetric method, with the aid of an analytical
PAIXÃO, A. A. et al.

balance with a resolution of $0.001 \mathrm{~g}$. The physical properties were determined when the moisture content was around $0.2385,0.2131,0.1825$ and 0.1523 (d.b.).

The moisture content of the beans was determined over $24 \mathrm{~h}$ by the greenhouse method at $105 \pm 3^{\circ} \mathrm{C}$ with three replications (BRASIL, 2009).

True density was determined in 25 beans, using a $50 \mathrm{~mL}$ graduated burette with a resolution of $0.01 \mathrm{~mL}$. The known weight of the beans was related to the known volume of a liquid, in this case sunflower oil, whose characteristics included minimum penetration into the pores of the beans.

The bulk density, in $\mathrm{kg} \mathrm{m}^{-3}$, was determined using an analytical balance with a resolution of 0.01 $\mathrm{g}$, and a container with a capacity of $0.55061 \mathrm{~L}$ (one dry pint), in five replications.

The porosity of the beans was indirectly determined based on the results for bulk and unit density, using Equation 1, as described by Mohsenin (1986):

$$
\varepsilon=\left(1-\frac{\rho_{a p}}{\rho_{u}}\right) \times 100
$$

where: $\varepsilon$ : porosity, $(\%) ; \rho_{a p}$ : bulk density, $\left(\mathrm{kg} \mathrm{m}^{-3}\right) ; \rho_{\mathrm{u}}$ : unit density, $\left(\mathrm{kg} \mathrm{m}^{-3}\right)$.

For each level of moisture, 15 beans were selected, and their characteristic dimensions along the orthogonal axes, as shown in Figure 1, were measured with a $0.01 \mathrm{~mm}$ digital calliper. In this way, it is possible to calculate the unit volume, sphericity, circularity, geometric diameter, projected area, surface area and surface to volume ratio.

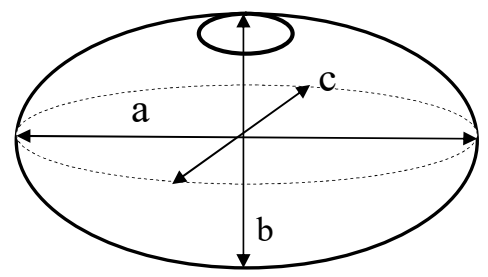

Figure 1. Schematic drawing of the bean, considered as a triaxial spheroid, with its characteristic dimensions.

The unit volume $\left(\mathrm{V}_{\mathrm{u}}\right)$, in $\mathrm{mm}^{3}$, was calculated according to Equation 2, as described by Mohsenin (1986).

$$
V_{u}=\frac{\pi(a b c)}{6}
$$

where: a: major axis, $(\mathrm{mm})$; b: intermediate axis, (mm); c: minor axis, (mm).
The sphericity (E), in \%, of the bean grain was calculated from Equation 3, as described by Mohsenin (1986).

$$
E=\left[\frac{(a b c)^{1 / 3}}{a}\right] \times 100
$$


Circularity (C) in \%, was verified in three projections: major axis, intermediate axis and minor axis, as shown in Figure 2, using Equation 4.

$$
C=\left(\frac{d_{i}}{d_{c}}\right) \times 100
$$

(A)

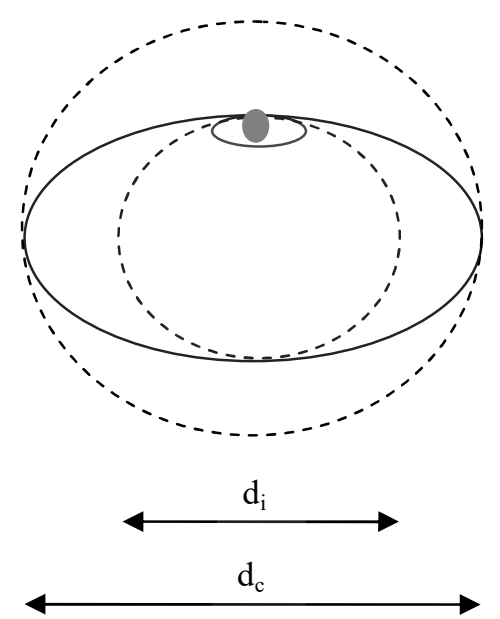

where: $\mathrm{d}_{\mathrm{i}}$ : diameter of the largest inscribed circle, $(\mathrm{mm}) ; \mathrm{d}_{\mathrm{c}}$ : diameter of the smallest circumscribed circle, $(\mathrm{mm})$.
(B)

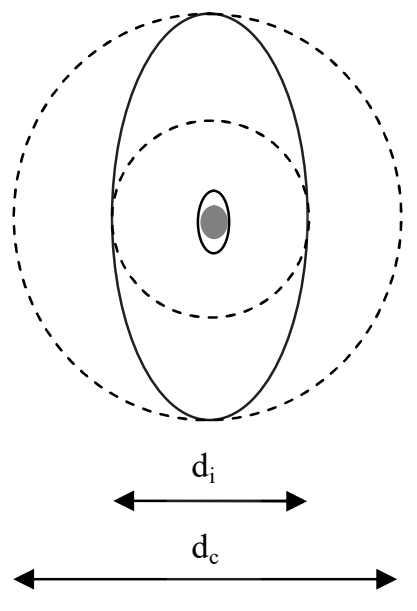

(C)

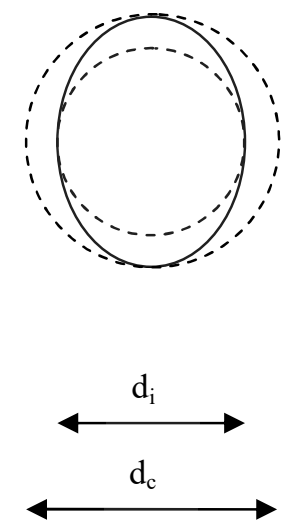

Figure 2. Schematic representation of the bean grain in three projections: major axis (A), intermediate axis (B) and minor axis $(\mathrm{C})$.

The geometric diameter of the product $\left(\mathrm{D}_{\mathrm{g}}\right)$, in $\mathrm{mm}$, was obtained from Equation 5, as proposed by Mohsenin (1986).

$$
D_{g}=(a b c)^{1 / 3}
$$

The projected area $\left(A_{p}\right)$, in $\mathrm{mm}^{2}$, was determined with Equation 6, and the results presented in $\mathrm{mm}^{2}$.

$$
A_{p}=\frac{\pi a b}{2}
$$

The surface area $\left(A_{s}\right)$, expressed in $\mathrm{mm}^{2}$, was calculated from the equation proposed by Mohsenin (1986), adjusting the main perpendicular axes to the product using the following expressions:

$$
A_{s}=\frac{\pi B^{2}}{2}+\frac{\pi a B}{2 E} \operatorname{sen}^{-1} E
$$

where:

$$
B=(b c)^{1 / 2}
$$

$$
E=\sqrt{1-\left(\frac{B}{a}\right)^{2}}
$$

where: B: geometric mean between the length and width, $\left(\mathrm{mm}^{2}\right)$; E: eccentricity.

The surface to volume ratio $(\mathrm{S} / \mathrm{V})$ of the product was determined as per Equation 10, with the results presented in $\mathrm{mm}^{-1}$.

$$
S / V=\frac{A_{s}}{V_{u}}
$$

To determine the 1000-grain weight, an analytical balance with an accuracy of $0.001 \mathrm{~g}$ was used, multiplying the mean weight of eight subsamples of 100 beans by 10 (BRASIL, 2009), with the results expressed in $\mathrm{kg}$.

Figure 3 shows the observed and estimated values for unit density, bulk density and the 1000grain weight in bean grain as a function of moisture content. 


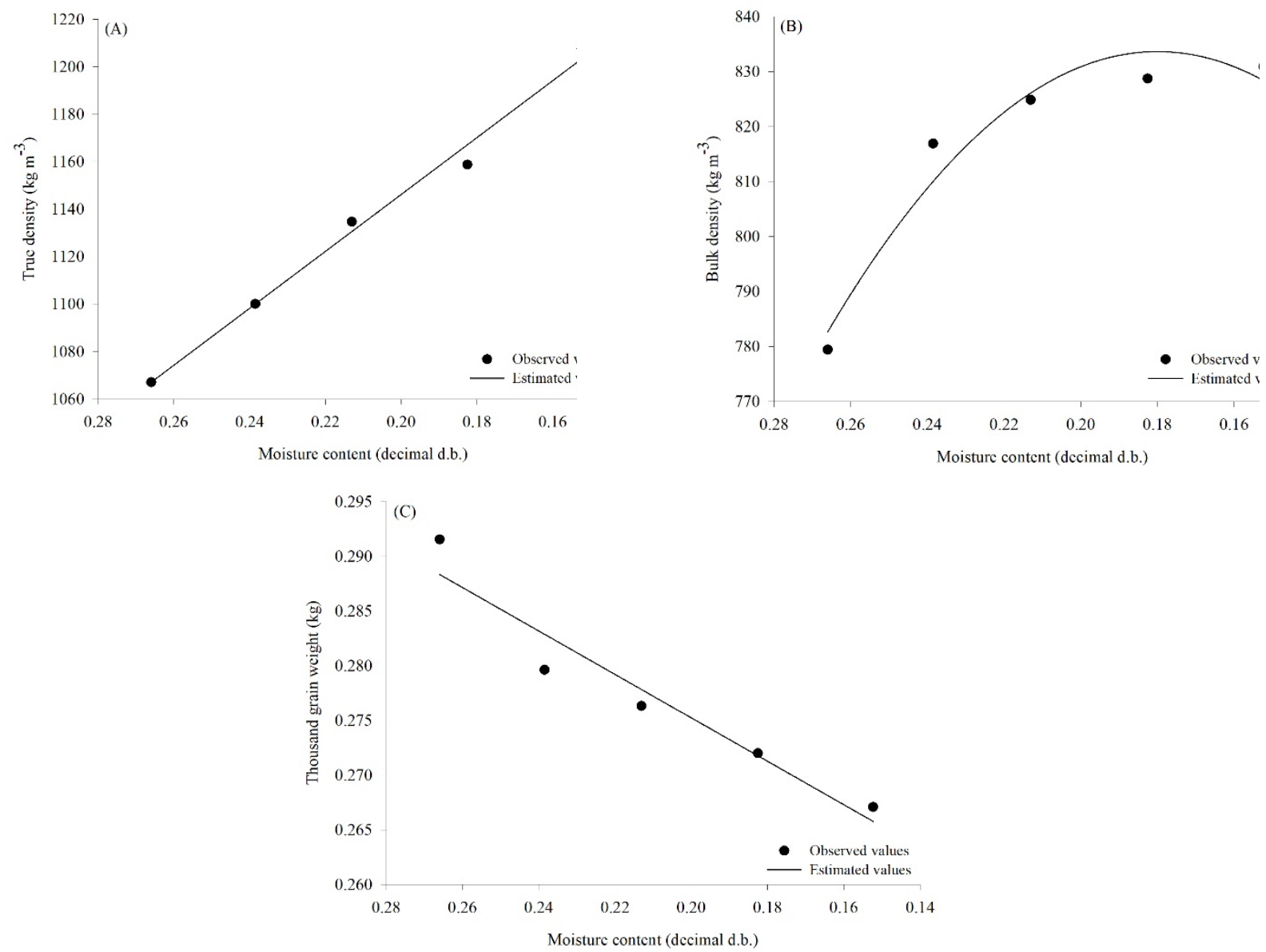

Figure 3. True density (A), bulk density (B) and 1000-grain weight (C) as a function of moisture content

The bulk and unit density of the beans (Figure $3 \mathrm{~A}$ and $3 \mathrm{~B}$ ) increased with the reduction in moisture content. This is due to the volume of the bean being proportionally greater than its weight at higher levels of moisture, which results in lower values for unit and bulk density.

The estimated values for unit and bulk density ranged from 1067.08 to $1207.61 \mathrm{~kg} \mathrm{~m}^{-3}$ and 779.38 to $830.86 \mathrm{~kg} \mathrm{~m}^{-3}$ respectively for a moisture content of 0.2660 to 0.1523 (decimal, d.b.). These results agree with those found by Resende et al. (2008) in the red bean, Davies and Zibokere, (2011) in the cowpea and Jesus et al., (2013) for bean seeds of cultivars Valente and Pontal.

A further analysis of Figure 3 shows that the variation in experimental values can be satisfactorily represented by second degree linear and polynomial models (Table 1) for unit and bulk density respectively.

The 1000-grain weight (Figure 3C) decreased linearly from 0.2915 to $0.2671 \mathrm{~kg}$ when the moisture content fell from 0.2660 to 0.1523 decimal, d.b. As such, a reduction rate of $0.1986 \mathrm{~kg}$ in the 1000-grain weight was seen for a one-unit decrease in moisture content (Table 1). Similar results were obtained by Bande et al. (2012), Araujo et al. (2014), Al-Mahasneh and Rababah (2007) and Martins et al. (2017). This phenomenon occurs during drying because the steam pressure in the beans is higher than that of the air, resulting in moisture being removed from the product.

The results for porosity in the bean grain can be seen in Figure 4.

Analysing Figure 4A, an increase in porosity values from 26.96 to $31.20 \%$ can be seen with the reduction in moisture content from 0.2660 to 0.1523 decimal d.b. The second order polynomial model best fitted the data (Table 1). Al-Mahasneh and Rababah (2007) also reported quadratic behaviour for porosity; however other authors found linear behaviour for this property (COŞKUNER; KARABABA, 2007; DAVIES; ZIBOKERE, 2011; KARABABA, 2006). 
Table 1. Models adjusted to the experimental values for physical properties in beans of the BRSMG Majestoso cultivar as a function of moisture content, with the coefficient of determination $\left(\mathrm{R}^{2}\right)$ and significance level $\left(\mathrm{P}_{\text {level }}\right)$ for each equation by F-test.

\begin{tabular}{ccccc}
\hline Physical property & Model & $\mathrm{R}^{2}(\%)$ & $\mathrm{F}$ & $\mathrm{P}_{\text {level }}$ \\
\hline True density & $\rho_{\mathrm{u}}=1386.07-1199.18 \times \mathrm{U}$ & 96.10 & 329.72 & 0.0004 \\
Bulk density & $\rho_{\mathrm{ap}}=610.45+2480.13 \times \mathrm{U}-6890.21 \times \mathrm{U}^{2}$ & 95.04 & 19.15 & 0.0496 \\
Porosity & $\varepsilon=62.46-299.36 \times \mathrm{U}+620.52 \times \mathrm{U}^{2}$ & 96.20 & 25.31 & 0.0380 \\
Sphericity & $\mathrm{E}=46.52+193.89 \times \mathrm{U}-508.17 \times \mathrm{U}^{2}$ & 99.07 & 106.15 & 0.0093 \\
Circularity & $\mathrm{C}=71.24-21.62 \times \mathrm{U}$ & 84.14 & 15.91 & 0.0282 \\
1000 -grain weight & $\mathrm{M}_{1000}=0.24+0.199 \times \mathrm{U}$ & 92.73 & 38.26 & 0.008 \\
\hline
\end{tabular}
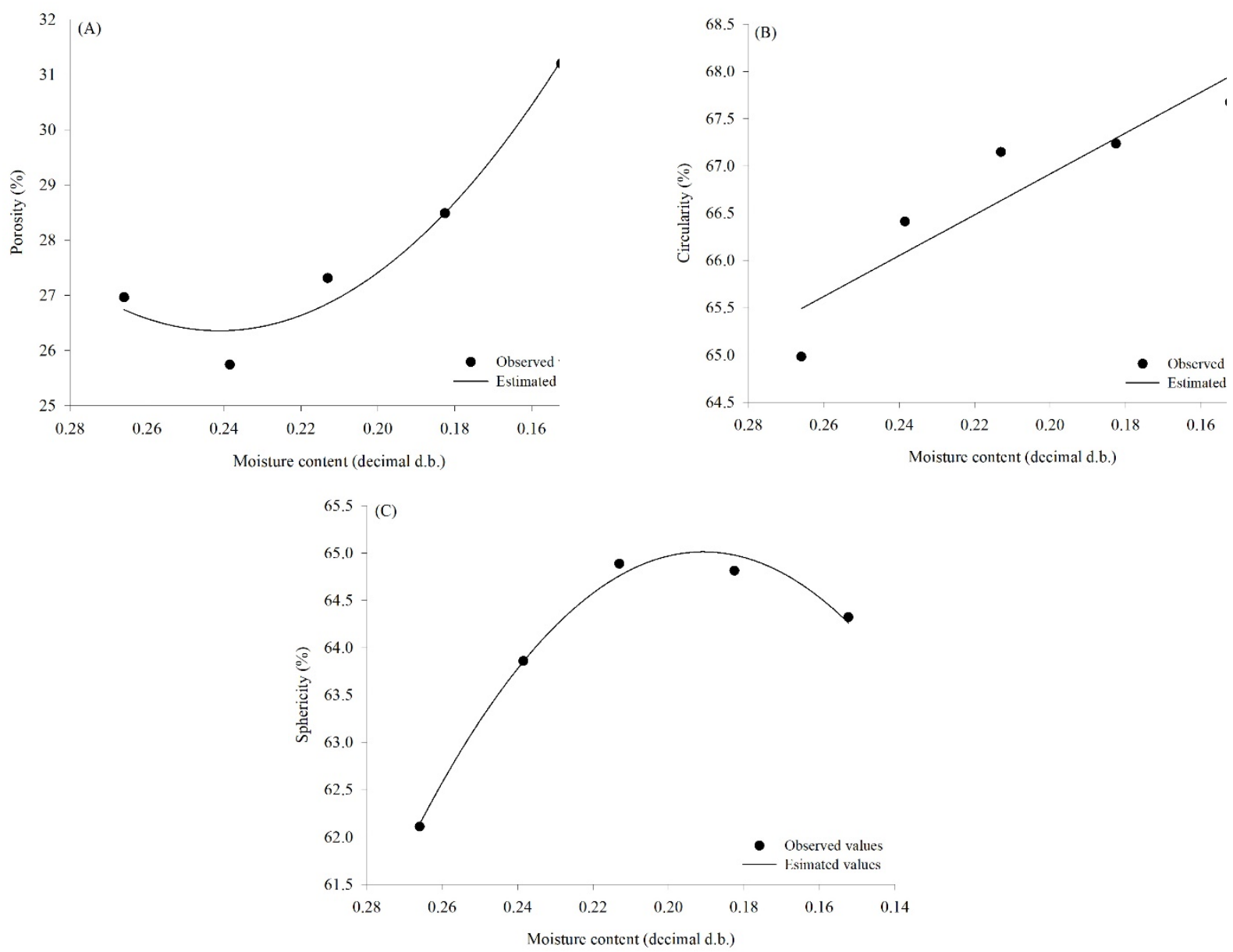

Figure 4. Porosity (A) circularity (B) and sphericity (C) in bean grain as a function of moisture content

Sphericity expresses the characteristic shape of a given solid in relation to a sphere, where the value indicates how much the product approaches a sphere, while circularity expresses the characteristic shape of a given solid relative to a circle.

There was an increase in the sphericity and circularity of the bean grain with drying (Figure 4B and $4 \mathrm{C}$ ). The sphericity increased from 62.11 to $64.32 \%$ and the circularity from 64.98 to $67.67 \%$ for the moisture content under study. In addition, the second degree and linear polynomial models (Table 1) showed a good fit for sphericity and circularity respectively. Both sphericity and circularity had a value of less than $80 \%$, demonstrating the impossibility of a spherical or circular classification, regardless of the moisture content of the beans.

Similar results were found by Guedes et al. (2011). This inverse relationship between sphericity, 
circularity and moisture content can be explained by beans of the pinto group being more elongated, so that beans with a higher moisture content remain far from circular or spherical in shape.

Table 2 shows the decrease in geometric diameter, unit volume, projected area and surface area for a reduction in moisture content, demonstrating the reduction in the perpendicular axes $(a, b$ and $c)$ during drying. Similar observations were made by Altuntas and Yildis (2007) in the common bean, by Davies and Zibokere (2011) in the common bean, by Goneli et al. (2011) in the castor bean, and by Payman et al. (2011) and Araujo et al. (2014) in the peanut.

Table 2. Geometric diameter, unit volume, projected area, surface area and surface to volume ratio in beans of the BRSMG Majestoso cultivar as a function of moisture content.

\begin{tabular}{cccccc}
\hline \multirow{2}{*}{ Moisture content (decimal, d.b.) } & $\mathrm{D}_{\mathrm{g}}$ & $\mathrm{V}_{\mathrm{u}}$ & $\mathrm{A}_{\mathrm{p}}$ & $\mathrm{A}_{\mathrm{s}}$ & $\mathrm{S} / \mathrm{V}$ \\
\cline { 2 - 6 } & $(\mathrm{mm})$ & $\left(\mathrm{mm}^{3}\right)$ & \multicolumn{2}{c}{$\left(\mathrm{mm}^{2}\right)$} & $\left(\mathrm{mm}^{-1}\right)$ \\
\hline 0.2660 & 7.34 & 2582.01 & 62.23 & 146.32 & 0.0567 \\
0.2385 & 7.39 & 2573.18 & 62.13 & 145.64 & 0.0566 \\
0.2131 & 7.39 & 2533.31 & 61.64 & 143.98 & 0.0568 \\
0.1825 & 7.39 & 2519.65 & 61.48 & 143.99 & 0.0571 \\
0.1523 & 7.23 & 2218.21 & 57.68 & 137.09 & 0.0618 \\
\hline
\end{tabular}

Reductions in the projected area and surface area of agricultural products due to a decrease in moisture content is related to the reduction in volume during the drying process. According to Sirisomboon et al. (2007), this data can be used to determine the lower size limit of transport units, such as a conveyors, bucket elevators and helical conveyors, and together with porosity, affects resistance to air flow through the layer of material. Generating such information is relevant to better understanding the drying process.

A further analysis of Table 2 shows an increase in the surface to volume ratio of the beans for a reduction in moisture content. According to Farinha (2008), if the factors involved in this process are only physical, the reduction in moisture content will be proportional to the surface to volume ratio and, assuming that the shape of the product remains constant, the surface to volume ratio increases with the reduction in size.

\section{ACKNOWLEDGMENT}

The authors would like to thank the Coordenação de Aperfeiçoamento Pessoal de Nível Superior - CAPES (Coordination for the Improvement of Higher Education Personnel) for the essential support and financial aid (Finance Code 001) and the Fundação de Amparo à Pesquisa do Estado de Minas Gerais - FAPEMIG (Minas Gerais Research Foundation) for funding the master scholarship.

RESUMO: Objetivou-se com o presente trabalho, avaliar o efeito da secagem sobre as características físicas de grãos de feijão cultivar BRSMG Majestoso. Foram utilizados grãos com teor de água inicial de aproximadamente 0,2660 b.s. (base seca), e submetidos à secagem com temperatura de $40{ }^{\circ} \mathrm{C}$. Foram determinadas as propriedades físicas: massa específica aparente, massa específica unitária, porosidade intergranular, massa de mil grãos, esfericidade, circularidade, diâmetro geométrico, volume unitário, área projetada, área superficial e a relação superfície/volume. Com base nos resultados obtidos conclui-se que a redução do teor de água dos grãos de feijão proporcionou aumento da massa específica aparente e unitária, porosidade, esfericidade, circularidade e relação superfície/volume. Em contrapartida, a massa de mil grãos, o diâmetro geométrico, o volume unitário, a área projetada e a área superficial diminuíram com a redução do teor de água dos grãos de feijão.

PALAVRAS-CHAVE: Área projeta. Circularidade. Esfericidade. Massa específica aparente. Phaseolus vulgaris. Porosidade. 


\section{REFERENCES}

AL-MAHASNEH, M. A.; RABABAH, T. M. Effect of moisture content on some physical properties of green wheat. Journal of Food Engineering, v. 79, n. 4, p. 1467-1473, 2007.

https://doi.org/10.1016/j.jfoodeng.2006.04.045

ALTUNTAS, E.; YILDIZ, M. Effects of moisture content on some physical and mechanical properties of faba bean (Viciafaba L.) grains. Journal of Food Engineering, v. 78, n. 1, p. 174-183, 2007.

https://doi.org/10.1016/j.jfoodeng.2005.09.013

ARAUJO, W. D.; GONELI, A. L. D.; SOUZA, C. M. A.; GONÇALVES, A. A.; VILHASANTI, H. C. B. Propriedades físicas dos grãos de amendoim durante a secagem. Revista Brasileira de Engenharia Agrícola e Ambiental, v. 18, n. 3, p. 279-286, 2014. http://dx.doi.org/10.1590/S1415-43662014000300006

BANDE, Y. M.; ADAM, N. M.; AZMI, Y.; JAMAREI, O. Moisture dependent physical and compression of bitter melon (Citrullus colocynthis lanatus) seeds. International Journal of Agricultural Research, v. 7, n. 5, p. 243-254, 2012. DOI: 10.3923/ijar.2012.243.254

BRASIL. Ministério da Agricultura e Reforma Agrária. Regras para análise de sementes. Brasília, DF: MAPA, 2009. 395p.

COŞKUNER, Y.; KARABABA, E. Some physical properties of flaxseed (Linum usitatissimum L.). Journal of Food Engineering, v. 78, n. 3, p. 1067-1073, 2007. https://doi.org/10.1016/j.jfoodeng.2005.12.017

DAVIES, R. M.; ZIBOKERE, D. S. Effects of moisture content on some physical and mechanical properties of three varieties of cowpea (Vigna unguiculata (L) Walp.). Agricultural Engineering International: CIGR Journal, v. 13, n. 1, p. 1-8, 2011.

Empresa de Pesquisa Agropecuária de Minas Gerais (EPAMIG). Cultivares de feijão recomendadas para o estado de Minas Gerais. Belo Horizonte, 2016. Available from: < http://www.epamig.br/download/cartilhacultivares-de-feijao-recomendadas-para-o-estado-de-minas-gerais/>. Accessed: Set.03, 2016.

FARINHA, L. R. L. Características físicas na perda da matéria fresca e evolução das propriedades reológicas e cor da cenoura cv. Brasília no armazenamento. 2008. Dissertação de Mestrado.

GONELI, A. L. D.; CORRÊA, P. C.; MAGALHÃES, F E. A.; BAPTESTINI, F. M. Contração volumétrica e forma dos frutos de mamona durante a secagem. Acta Scientiarum. Agronomy, v. 23, n. 1, p. 1-8, 2011. http://dx.doi.org/10.4025/actasciagron.v33i1.4629.

GUEDES, M. A.; MATA, M. E. R. M. C.; DUARTE, M. E. M.; FARIAS, P. A. Caracterização física de grãos de soja utilizando-se processamento digital de imagens. Revista Brasileira de Produtos Agroindustriais, v. 13, n. 3, p. 279-294, 2011. https://doi.org/10.15871/1517-8595/rbpa.v13n3p279-294

JESUS, F. F.; SOUZA, R. T. G.; TEIXEIRA, G. C. S.; TEIXEIRA, I. R.; DEVILLA, I. A. Propriedades físicas de sementes de feijão em função de teores de água. Engenharia na Agricultura, v. 21, n. 1, p. 9-18, 2013. https://doi.org/10.13083/1414-3984.v21n01a01

MARTINS, E. A. S.; GONELI, A. L. D.; HARTMANN FILHO, C. P.; MAUAD, M.; SIQUEIRA, V. C.; GONÇALVES, A. A. Physical properties of safflower grains. Part I: Geometric and gravimetric characteristics. Revista Brasileira de Engenharia Agrícola e Ambiental, v. 21, n. 5, p. 344-349, 2017.

http://dx.doi.org/10.1590/1807-1929/agriambi.v21n5p344-349

MATA, M. E. R. M. C.; DUARTE, M. E. M. Porosidade intergranular de produtos agrícolas. Revista Brasileira de Produtos Agroindustriais, v. 4, n. 1, p. 79-93, 2002. https://doi.org/10.15871/15178595/rbpa.v4n1p79-93 
MOHSENIN, N. N. (Physical properties of plant and animal materials. New York: Gordon and Breach, 1986. 841p.

PAYMAN, S. H.; AJDADI, F. R.; BAGHERI, I.; ALIZADETH, M. R. Effect of moisture content on some engineering properties of peanut varieties. Journal of Food, Agriculture \& Environment, v. 9, p. 326-331, 2011.

RESENDE, O.; CORRÊA, P. C.; GONELI, A. L. D.; CECON, P. R. Forma, tamanho e contração volumétrica do feijão (Phaseolus vulgaris L.) durante a secagem. Revista Brasileira de Produtos Agroindustriais, v. 7, n. 1, p. 15-24, 2005. https://doi.org/10.15871/1517-8595/rbpa.v7n1p15-24

RESENDE, O.; CORRÊA, P. C.; GONELI, A. L. D.; RIBEIRO, D. M. Propriedades físicas do feijão durante a secagem: Determinação e modelagem. Ciência e Agrotecnologia, v. 32, n. 1, p. 225-230, 2008.

http://dx.doi.org/10.1590/S1413-70542008000100033

SIRISOMBOON, P.; KITCHAIYA, P.; PHOLPHO, T.; MAHUTTANYAVANITCH, W. Physical and mechanical properties of Jatropha curcas L. fruits, nuts and kernels. Biosystems Engineering, v. 97, n. 2, p. 201-207, 2007. https://doi.org/10.1016/j.biosystemseng.2007.02.011 